\title{
The Application Value of Interleukin-10 and Interleukin-15 in Osteoporosis
}

\author{
Tianxiang Lei ${ }^{1}$, Meng Wang ${ }^{2}$, Chengyan Zuo ${ }^{3 *}$, Huijun Xu ${ }^{1}$ \\ ${ }^{1}$ Institute of Integrated Chinese and Western Medicine, Basic Medical College of Qingdao University, Qingdao, China \\ ${ }^{2}$ Department of Pharmacy, Linyi People's Hospital, Linyi, China \\ ${ }^{3}$ Department of Traditional Chinese Medicine, Lanling Economic Development Area Hospital, Linyi, China \\ Email: *395682852@qq.om
}

How to cite this paper: Lei, T.X., Wang, M., Zuo, C.Y. and Xu, H.J. (2021) The Application Value of Interleukin-10 and Interleukin-15 in Osteoporosis. Open Access Library Journal, 8: e7279.

https://doi.org/10.4236/oalib.1107279

Received: March 3, 2021

Accepted: March 26, 2021

Published: March 29, 2021

Copyright $\odot 2021$ by author(s) and Open Access Library Inc.

This work is licensed under the Creative Commons Attribution International License (CC BY 4.0).

http://creativecommons.org/licenses/by/4.0/

\section{(c) (i) Open Access}

\begin{abstract}
Objective: To investigate the effects of cytokines IL-10 and IL-15 in osteoporosis, and to provide a basis for the prevention and treatment of osteoporosis. Methods: A total of 101 subjects who underwent bone density testing in Linyi People's Hospital from January 2018-December 2019 were selected and divided into normal bone density group, osteopenia group and osteoporosis group according to their bone density. At the same time, the peripheral serum IL-10 and IL-15 levels of subjects were detected. Results: The serum IL-10 and IL-15 levels of subjects with normal bone density were significantly higher than those of subjects with bone loss $(t=5.31, P<0.001)(t=6.87, P<$ $0.001)$ and osteoporosis. In the subjects $(t=5.38, P<0.001)(t=5.30, P<$ $0.001)$, the bone mineral density of the lumbar spine L1-L4 was positively correlated with serum IL-15 levels $(r=0.216, P=0.030)$, but with IL-10 No correlation $(r=-0.025, P=0.801)$. Femoral neck bone mineral density was positively correlated with serum IL-10 levels $(r=0.209, P=0.036)$, and femoral neck bone mineral density was positively correlated with serum IL-15 levels $(r=0.405, P<0.001)$. Stepwise regression analysis shows that IL-15 is closely related to bone density. Conclusion: Serum IL-10 and IL-15 have a protective effect on bone mass. Two anti-inflammatory cytokines play an important role in the occurrence and development of osteoporosis. Low levels of serum IL-10 and IL-15 have a protective effect on bone mass. Bone loss and osteoporosis have certain evaluation value, which can be used to prevent the occurrence of osteoporosis, reduce the risk of fracture, and reduce the difficulty and burden of nursing.
\end{abstract}

\section{Subject Areas}

Nursing, Orthopedics 


\section{Keywords}

Osteoporosis, Interleukin 10, Interleukin 15, Bone loss

\section{1. 研究背景}

骨粗鬆症は高齢者だけの特殊な病気、中国の人口の高齢化につれて平 均余命が延びる可能性がある、骨粗鬆症の発生率は年々増加しています [1]。骨粗鬆症では転倒により容易に骨折し、骨折すると患者さんの動きが 制限されるため、介護がさらに困難になります。既存の研究では、慢性炎 症が成人の骨塩密度の低下に関連していることが示されています。インタ 一ロイキン 6 (IL-6) と腫瘍壞死因子 $\alpha$ (TNF- $\alpha$ ) は炎症性サイトカインであ り、骨粗鬆症の悪化とともにそれらのレベルが上昇することが研究により 示され、両方とも Wnt/ $\beta$-カテニンシグナル伝達経路を阻害し、OPG/RANKL を引き起こす可能性があります/RANK システムバランス障害およびその 他の経路は、骨代謝に影響を及ぼし、骨量減少を悪化させます[2] [3] [4]。 既存の研究では、抗炎症性サイトカインとしてのインターロイキン 10 (IL-10)とインターロイキン 15 (IL-15)が、体内の炎症の調節に重要な役割を 果たしていることが示されています[5] [6]。そのため、本研究は骨量の減少 と骨粗鬆症患者の血清 IL-10、IL-15 を測定し、前向きに IL-10、IL-15 の患 者の骨密度に対する影響を評価し、骨粗鬆症の予防評価に一定の参考を提 供し、関連患者の看護難度と看護の経済負担を減少するために応用する。

\section{2. 材料と方法}

\section{1. 研究对象}

2018 年 1 月から 2019 年 12 月までの間に臨沂市人民病院で骨密度測定を行 つた被験者 101 人を選び、患者の骨密度測定の $\mathrm{T}$ 值採点(T-score)状況に基 づいて、1994 年 WHO 標準[7]を参考して、正常群( $\mathrm{T}$ 值 $\geq-1.0 \mathrm{SD} ; \mathrm{n}=47$ )、 骨量減少群 $(-2.5 \mathrm{SD}<\mathrm{T}$ 值 $<-1.0 \mathrm{SD} ; \mathrm{n}=40)$ と骨粗鬆症群 $(\mathrm{T}$ 值 $\leq-2.5 \mathrm{SD}$; $\mathrm{N}=14$ )。(本研究は関連倫理審査の承認を得たので、被験者はいずれもイン フォームドコンセントに署名した)

診断標準: 1994 年 $\mathrm{WHO}$ 標準、骨密度測定の $\mathrm{T}$ 值を参考とし、 $\mathrm{T}$ 值 $\geq$ $-1.0 \mathrm{SD}$ は骨量正常、 $-2.5 \mathrm{SD}<\mathrm{T}$ 值 $<-1.0 \mathrm{SD}$ は骨量減少、 $\mathrm{T}$ 值 $\leq-2.5 \mathrm{SD}$ は骨粗鬆である $[7] 。$

標準に入れる：1）関連診断基準に符合する被験者；2）年齢 20 歳以上 骨密度テストに符合して $\mathrm{T}$ 值年齢を獲得した者;

除外基準：1）年齢 <20 歳の者，2）他の疾患を有する被験者，3）グル ココルチコイドなどの骨密度を破壞する薬物を長期投与した被験者。

\section{2. アプローチ}

骨密度測定: 双エネルギーX 線骨密度計(GE, USA)を用いて被験者に対して 
腰椎 L1 L4 と大腿骨の骨密度測定を行った。酵素結合免疫吸着測定法を用 いて患者の血清 IL-10(No.)を測定した。BY S 10066 B, 博研, 中国上海), IL-15 レベル(No.BY S 10061 B, 博研, 中国上海)。

\section{3. 統計学的アプローチ}

SPSS 22.0 ソフトウェアを用いて統計学的分析を行った。計量資料は平 均数士標準偏差 $(\bar{x} \pm s)$ 或いは中央值で表し、グループ間比較は独立サンプ $ル t$ 検定を用い、相関性分析は Pearson 相関性分析を用い、 $P<0.05$ を統計 学的有意差があった。

\section{3. 結果}

正常群の腰椎 L1 L4 骨密度は骨粗鬆症群より明らかに高く $(\mathrm{t}=2.57, \mathrm{P}$ $=0.013)$ 、正常群の大腿骨の骨密度は骨量減少群 $(\mathrm{t}=4.09, \mathrm{P}<0.001)$ と骨粗鬆 症群 $(\mathrm{t}=5.38, \mathrm{P}<0.001)$ より明らかに高く、骨量減少群の大腿骨の骨密度は 骨粗鬆群より明らかに高かった $(\mathrm{t}=3.22, \mathrm{P}=0.002)$ 、その中で骨粗鬆症群の 年齢 $(63.21 \pm 4.93$ 歳)は正常群 $(55.50 \pm 15.74$ 歳 $)(t=4.24, P<0.001)$ と骨量減少 群(55.76 \pm 15.81 歳) $(t=2.76, P=0.008)$ より有意に高かった。(表 1 参照)

正常群 IL-10 と IL-15 は骨量減少群より明らかに高かった $(t=5.31, P<$ $0.001)(t=6.87, P<0.001)$ と骨粗鬆症群 $(t=5.38, P<0.001)(t=5.30 P<0.001)$ 。 (表 2 参照)

Pearson 相関分析では, 腰椎 L1 L4 骨密度は血清 IL-15 レベルと正の相 関関係を示したが $(r=0.216, P=0.030), \quad \mathrm{IL}-10$ とは相関がなかった $(r=$ $-0.025, P=0.801)$ 。大腿骨の骨密度は血清 IL-10 レベルと正の相関関係を呈 し $(r=0.209, P=0.036)$, 大腿骨の骨密度は血清 IL-15 レベルと正の相関関係 を示した $(r=0.405, P<0.001)$ 。

関連データは横断面分析を行い、逐次法により IL-15 は腰椎 L 1-L 4 骨 密度と脛骨骨密度と相関性があることを表明した。局所的に重み付けされ た散布図平滑化は両者が IL-15 と関数的に増加傾向にあることを示した(表 3 , 表 4, 図 1 参照)。

\section{表 1.3 群の被験者の骨密度と $\mathrm{T}$ 值の比較}

\begin{tabular}{cccc}
\hline & 骨粗鬆症群 & 骨量減少群 & 正常群 \\
\hline 腰椎 $\mathrm{L} 1 \sim \mathrm{L} 4$ 骨密度 $\left(\mathrm{g} / \mathrm{cm}^{2}\right)$ & $0.93 \pm 0.41$ & $1.21 \pm 0.56$ & $1.39 \pm 0.62^{\mathrm{a}}$ \\
大腿骨の骨密度 $\left(\mathrm{g} / \mathrm{cm}^{2}\right)$ & $0.82 \pm 0.09$ & $0.96 \pm 0.14^{\mathrm{a}}$ & $1.10 \pm 0.18^{\mathrm{ab}}$ \\
\hline
\end{tabular}

a $は$ 骨粗鬆症群と比較して有意差が認められた; ${ }^{\mathrm{b}}$ 骨量減少群と比較して有意差が認められた

表 2.3 群の被験者の血清 IL-10 と IL-15 レベルを比較した

\begin{tabular}{cccc}
\hline & 骨粗噤症群 & 骨量減少群 & 正常群 \\
\hline IL-10 $(\mathrm{pg} / \mathrm{mL})$ & $9.73 \pm 5.38$ & $11.20 \pm 8.01$ & $20.95 \pm 9.09^{\mathrm{ab}}$ \\
$\mathrm{IL}-15(\mathrm{pg} / \mathrm{mL})$ & $9.47 \pm 6.02$ & $10.34 \pm 6.30$ & $19.54 \pm 6.18^{\mathrm{ab}}$ \\
\hline
\end{tabular}

a 
表 3. 腰椎 L 1-L 4 骨密度と 2 種類のサイトカイン横断面解析

\begin{tabular}{ccccccc}
\hline & $\boldsymbol{\beta}$ & $\boldsymbol{P}$ & $(95 \% \mathrm{CI})$ & $\boldsymbol{\beta}$-年齢性別調整 & $\boldsymbol{P}$ & $(95 \% \mathrm{CI})$ \\
\hline $\mathrm{IL}-10$ & -0.004 & 0.427 & $(-0.015 \sim 0.006)$ & -0.005 & 0.404 & $(-0.015 \sim 0.006)$ \\
$\mathrm{IL}-15$ & 0.02 & 0.012 & $(0.004 \sim 0.028)$ & 0.02 & 0.015 & $(0.003 \sim 0.029)$ \\
\hline
\end{tabular}

表 4. 大腿骨の骨密度と 2 種類のサイトカイン横断面解析

\begin{tabular}{ccccccc}
\hline & $\boldsymbol{\beta}$ & $\boldsymbol{P}$ & $(95 \% \mathrm{CI})$ & $\boldsymbol{\beta}$-年齢性別調整 & $\boldsymbol{P}$ & $(95 \% \mathrm{CI})$ \\
\hline $\mathrm{IL}-10$ & 0.002 & 0.344 & $(-0.002 \sim 0.005)$ & 0.001 & 0.452 & $(-0.002 \sim 0.004)$ \\
$\mathrm{IL}-15$ & 0.01 & $<0.001$ & $(0.004 \sim 0.011)$ & 0.01 & $<0.001$ & $(0.003 \sim 0.011)$ \\
\hline
\end{tabular}

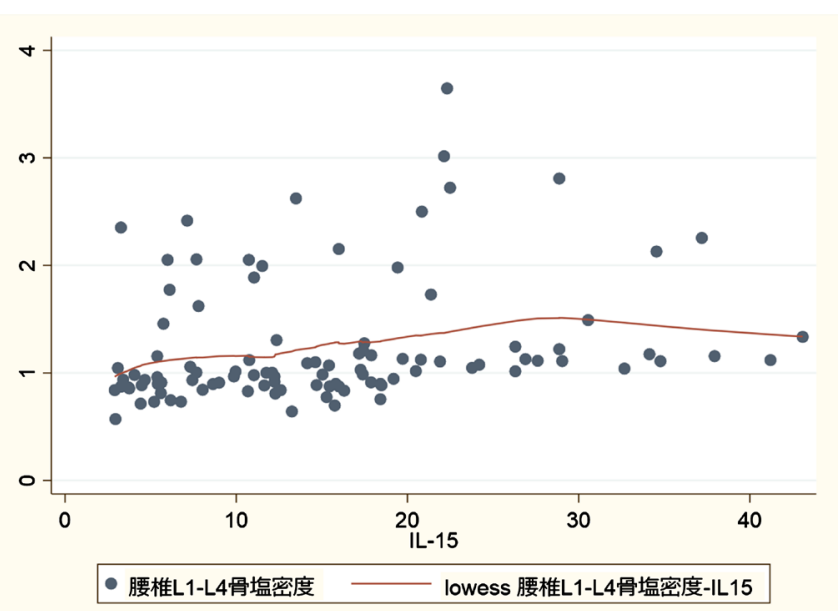

(a)

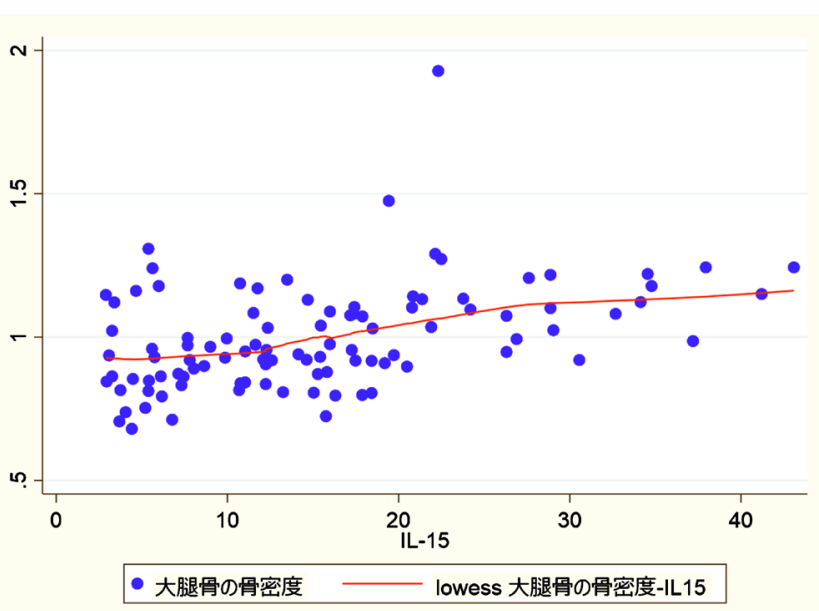

(b)

図 1. 骨密度と IL-15 局所的に重み付けされた散布図平滑化分析結果: (a) 腰椎 L 1-L 4 骨密度と IL-15, (b) 大腿骨の骨密 度と IL-15

\section{4. 討論}

骨損失はょく見られる自己免疫と炎症性疾患状態であり $[8] 、 T N F-\alpha$ は 破骨活性化、骨再吸収と関係があると考えられ、上昇した TNF- $\alpha$ は破骨細 胞と末梢血中の前破骨細胞を増加させ、しかも極めて少量の TNF- $\alpha$ は RANKL の骨吸収促進効果を著しく増加させ、骨吸収を促進し、それによっ て骨粗鬆症を引き起こす [9] [10]。もう一つの炎症因子 IL-6 も骨粗鬆症を引 き起こす炎症性サイトカインの一つである[10]。IL-10 は抗炎症性サイトカ インであり、炎症性サイトカインとケモカインを下げることができ、TNF- $\alpha$ と IL-6 を抑制することができ、しかも破骨細胞の吸収を抑制し、骨芽細胞 の形成を調節することによって骨量の維持を助けることができる。研究に より、IL-10の骨量に対する保護は以下の機序と関係がある可能性があり、 IL-10は骨保護素の発現を調節することができ、NF-K 受容体活性化剂の発 現を低下させ、活性化した $\mathrm{T}$ 細胞の核因子 $\mathrm{C} 1$ 発現を減少させ、それによ って破骨細胞形成を抑制し、IL-10 はまた転化成長因子- $\beta 1$ の分泌を増加さ せて骨芽細胞分化を促進することができる[11] [12] [13]。以上ょり，高レべ ルの IL-10 は骨量を保護する意義があり, 本研究でも大腿骨澒部骨密度は 
血清 IL-10 レベルと正の相関関係 $(r=0.209, P=0.036)$ を示したが, 腰椎 L1 L4 骨密度には相関を示さず, ょり多くのデータ支持を得るための検討 が必要である。

IL-15 は炎症促進と抗炎症の二重効果を有するサイトカインであるが、 現在の研究により、骨格に関連する疾病過程中に IL-15 は抗炎症効果を発 揮する可能性があり、積極的な役割を果たしていることが示された[6] [14]。 研究により、IL-15 は筋発生を促進でき、そして炎症を介した骨格筋萎縮を 抑制できる可能性があり、IL-15は炎症を介した骨格筋萎縮を軽減する有効 な治療標的である可能性がある[15]。骨格筋萎縮は骨粗鬆症の発生と密接に 関連しており、現在すでに筋量の増加は骨量の増加に役立ち、骨粗鬆症の リスクを低下させることが実証されており、特に近年の少筋症の概念の提 出は、筋少症と骨粗鬆症が伴うことが発見され、更に筋量の維持が骨粗鬆 症予防に対する作用を表明した[16] [17] [18]。しかし、現在比較的に少ない 研究により、IL-15 は骨密度と関係がある可能性があることを表明したが、 現在機序がまだ明確でないだけでなく、十分な臨床証拠が不足している [19]。本研究では腰椎 L 1-L 4 骨密度, 大腿骨頚部骨密度ともに血清 IL-15 レベルと正の相関関係を示し $(\beta=0.02, P=0.012),(\beta=0.01, P<0.001)$, これ までの仮定である IL-15 が骨量に対して保護効果を発揮し，その機序が骨 格筋量の保護作用に関与している可能性が示唆されたが，ょり深い検討が 必要である。この研究にはサンプルサイズが小さいという制限があり、い くつかの交絡因子は考慮されていません。今後の研究でさらに議論されま す。

つまり、本研究により、IL-15は骨量レベルの維持と関係がある可能性 があり、骨量に対して保護作用があり、しかも低レベルの血清 IL-15は骨 粗鬆症と骨折の評価に対して提示作用がある可能性があり、骨粗鬆症と骨 折の予防に重要な価值があり、骨粗鬆症の高リスク群に対して重要な価值 があることを示した。例えば老人と長期に各種の骨損傷のある薬物を服用 した人群の血清 IL-15 の測定は一定の価值があり、事前に干与措置をとる ことができ、骨粗鬆の発生を減少し、同時に関連する人群の看護の負担と 難度を減少することができる。

\section{Conflicts of Interest}

The authors declare no conflicts of interest regarding the publication of this paper.

\section{References}

[1] Tosi, L.L. and Lane, J.M. (1998) Osteoporosis Prevention and the Orthopaedic Surgeon: When Fracture Care Is Not Enough. The Journal of Bone and Joint Surgery, 80, 1567-1569. https://doi.org/10.2106/00004623-199811000-00001

[2] 王三杏, 谢雍, 董矜, 等. 成人骨密度与慢性炎症的相关性分析 [J]. 标记免疫分 析与临床, 2016, 23(7): 717-721.

[3] 李伟, 罗南萍, 孙晓明, 等. IL-6、TNF- $\alpha$ 在老年骨质疏松症中的临床价值探讨 [J]. 
放射免疫学杂志, 2008, 21(2): 106-108.

[4] 蒲嘉骐, 郝杰. 特殊人群骨质疏松症研究进展 [J]. 中国骨质疏松杂志, 2015, 21(6): 100-104.

[5] Tural, S., Alayli, G., Kara, N., et al. (2013) Association between Osteoporosis and Polymorphisms of the IL-10 and TGF-Beta Genes in Turkish Postmenopausal Women. Human Immunology, 74, 1179-1183.

https://doi.org/10.1016/j.humimm.2013.03.005

[6] Perera, P.Y., Lichy, J.H., Waldmann, T.A., et al. (2012) The Role of Interleukin-15 in Inflammation and Immune Responses to Infection: Implications for Its Therapeutic Use. Microbes \& Infection, 14, 247-261.

https://doi.org/10.1016/j.micinf.2011.10.006

[7] 杨鸿兵, 郭美灵, 何旭颖, 等. 63 例 QCT 腰椎骨骨密度测量与 DTX-200 双能 X 前 臂骨骨密度测量对比分析[J]. 中国骨质疏松杂志, 2011, 17(3): 38-41.

[8] Ginaldi, L., Benedetto, M.C.D. and Martinis, M.D. (2005) Osteoporosis, Inflammation and Ageing. Immunity \& Ageing, 2, Article No. 14.

https://doi.org/10.1186/1742-4933-2-14

[9] 夏婷，李双庆. 炎症相关骨质疏松症的发病机制[J]. 中国骨质疏松杂志，2015, 21(1): 117-120.

[10] 杜艳萍, 程群. 炎症在骨质疏松发生中的作用与机制研究新进展 [J]. 老年医学与 保健, 2013, 19(6): 427-431.

[11] Strle, K., Mccusker, R.H., Tran, L., et al. (2007) Novel Activity of an Anti-Inflammatory Cytokine. Journal of Neuroimmunology, 188, 48-55. https://doi.org/10.1016/j.jneuroim.2007.05.003

[12] 胡道军, 罗欣, 黄海良, 等. IL-10 抑制脂多糖诱导的 Hela 细胞 IL-15 和 IL-6 转录 [J]. 中国生化药物杂志, 2010, 31(2): 85-89.

[13] Zhang, Q., Chen, B., Yan, F., et al. (2014) Interleukin-10 Inhibits Bone Resorption: A Potential Therapeutic Strategy in Periodontitis and Other Bone Loss Diseases. BioMed Research International, 2014, Article ID: 284836.

https://doi.org/10.1155/2014/284836

[14] Ishimitsu, R., Nishimura, H., Yajima, T., et al. (2001) Overexpression of IL-15 in Vivo Enhances Tc1 Response, Which Inhibits Allergic Inflammation in a Murine Model of Asthma. Journal of Immunology, 166, 1991-2001.

https://doi.org/10.4049/jimmunol.166.3.1991

[15] O'Leary, M.F., Wallace, G.R., Bennett, A.J., et al. (2017) IL-15 Promotes Human Myogenesis and Mitigates the Detrimental Effects of TNF $\alpha$ on Myotube Development. Scientific Reports, 7, Article No. 12997.

https://doi.org/10.1038/s41598-017-13479-w

[16] 小尾, 佳嗣, 濱野, 高行. CKD とビタミン D 欠乏(第 15 回日本骨粗鬆症学会 シ ンポジウム $6 \mathrm{CKD}$ 患者の骨) [J]. オステオポローシスジャパン: 日本骨粗鬆症 学会雑誌, 2014, 22: 34-38.

[17] 马永成, 郝永强. 肌肉与骨质疏松症[J]. 国际骨科学杂志, 2006, 27(6): 334-336.

[18] 王建华, 冯玫, 许佳佳, 等. 骨骼肌质量与骨含量的相关性研究 [J]. 中国药物与 临床, 2019, 19(6): 960-961.

[19] Kiel, D. (1995) National Osteoporosis Foundation Working Group in Vertebral Fractures. Journal of Bone and Mineral Research, 10, 518-523. 